\title{
Self-assembled energetic coordination polymers based on multidentate pentazole cyclo- $\mathrm{N}_{5}{ }^{-}$
}

\author{
Peng-Cheng Wang ${ }^{\dagger}$, Yuan-Gang Xu${ }^{\dagger}$, Qian Wang, Yan-Li Shao, Qiu-Han Lin ${ }^{*}$ and Ming Lu*
}

\begin{abstract}
Coordination to form polymer is emerging as a new technology for modifying or enhancing the properties of the existed energetic substances in energetic materials area. In this work, guanidine cation $\mathrm{CN}_{3} \mathrm{H}_{6}^{+}(\mathrm{Gu})$ and 3-amino-1,2,4triazole $\mathrm{C}_{2} \mathrm{H}_{4} \mathrm{~N}_{4}(\mathrm{ATz})$ were crystallized into $\mathrm{NaN}_{5}$ and two novel energetic coordination polymers $(\mathrm{CPs}),\left(\mathrm{NaN}_{5}\right)_{5}\left[\left(\mathrm{CH}_{6}-\right.\right.$ $\left.\left.\mathrm{N}_{3}\right) \mathrm{N}_{5}\right]\left(\mathrm{N}_{5}\right)_{3}^{-}$(1) and $\left(\mathrm{NaN}_{5}\right)_{2}\left(\mathrm{C}_{2} \mathrm{H}_{4} \mathrm{~N}_{4}\right)$ (2) were prepared respectively via a self-assembly process. The crystal structure reveals the co-existence of the chelating pentazole anion and organic component in the solid state. In polymer $1, \mathrm{Na}^{+}$and $\mathrm{N}_{5}{ }^{-}$were coordinated to form a cage structure in which guanidine cation $\left[\mathrm{C}\left(\mathrm{NH}_{2}\right)_{3}\right]^{+}$was trapped; for polymer 2 , a mixedligand system was observed; $\mathrm{N}_{5}{ }^{-}$and ATz coordinate separately with $\mathrm{Na}^{+}$and form two independent but interweaved nets. In this way, coordination polymer has been successfully utilized to modify specific properties of energetic materials through crystallization. Benefiting from the coordination and weak interactions, the decomposition temperatures of both polymers increase from $111^{\circ} \mathrm{C}\left(1 \mathrm{D}\right.$ structure $\left[\mathrm{Na}\left(\mathrm{H}_{2} \mathrm{O}\right)\left(\mathrm{N}_{5}\right)\right]$ $.2 \mathrm{H}_{2} \mathrm{O}$ ) to 118.4 and $126.5^{\circ} \mathrm{C}$ respectively. Moreover, no crystallized $\mathrm{H}_{2} \mathrm{O}$ was generated in products to afford the anhydrous compounds of pentazole salts with high heats of formation $\left(>800 \mathrm{~kJ} \mathrm{~mol}^{-1}\right)$. Compared to traditional energetic materials, the advantage in heats of formation is still obvious for the cyclo- $\mathrm{N}_{5}{ }^{-}$based CPs, which highlights cyclo- $\mathrm{N}_{5}{ }^{-}$as a promising energetic precursor for high energy density materials (HEDMs).
\end{abstract}

Keywords: pentazole, energetic coordination polymers, self-assembled, stability, high heats of formation

\section{INTRODUCTION}

In the last two decades, nitrogen-rich and poly-nitrogen compounds have received significant attention due to their interesting chemical properties and potentiality to serve as environmentally friendly high energy density materials (HEDMs) [1-3]. These species release a large amount of energy during the decomposition of single/ double bonded nitrogen in the condensed phase into triple-bonded gas-phase inert $\mathrm{N}_{2}$ molecules. Nitrogenrich compounds constitute a large family of interesting compounds, which are certainly no less active than the traditional CHON energetic materials [4,5]. It is worth noting that they have boosted the development of energetic salts [6-8], energetic coordination polymers (CPs, also defined as energetic metal organic frameworks (MOFs) in some cases) [9-11], and energetic co-crystals $[12,13]$, and thus significantly expanded the range of energetic materials.

In contrast, the experimental difficulties in studying poly-nitrogen compounds have delayed their contribution to the field of energetic materials. For a very long time, only the azide anion was used to produce energetic salts or simple CPs [14,15]. In 1999, a major breakthrough in poly-nitrogen area was achieved with the preparation of the $\mathrm{N}_{5}{ }^{+}$ion and its relative stable energetic salts were subsequently synthesized [16,17]. Unfortunately, owing to the unstable bonding interactions with other anions, further developments of $\mathrm{N}_{5}{ }^{+}$ion have been limited. The pentazole anion cyclo- $\mathrm{N}_{5}{ }^{-}$was first detected in 2002 via mass spectrometry (MS) [18,19] and was not adopted for bulk production until recently [2026]. However, the anhydrous pentazole sample $\mathrm{NaN}_{5}$ [21] and $\mathrm{CsN}_{5}$ [22] were only observed under extreme high pressure and the metal-pentazole hydrates [24-26] decomposed in the range of $100-110^{\circ} \mathrm{C}$. Both high pressure preparing method and hydrates samples are the disadvantages in terms of their application. Fortunately, the cyclo- $\mathrm{N}_{5}^{-}$anion shows good adaptability to take part in ionic, coordination, and hydrogen bonding interactions $[24,27]$. Furthermore, there is a possibility to form either energetic CPs or co-crystals by self-assembling, which is a

${ }^{1}$ School of Chemical Engineering, Nanjing University of Science and Technology, Nanjing, 210094, China

These authors contributed equally to this study.

* Corresponding authors (emails: linqh@njust.edu.cn (Lin QH); luming@njust.edu.cn (Lu M)) 
new technology for modifying or enhancing the properties of existing energetic substances.

In this work, anhydrous coordination polymers $\left(\mathrm{NaN}_{5}\right)_{5}\left[\left(\mathrm{CH}_{6} \mathrm{~N}_{3}\right) \mathrm{N}_{5}\right]\left(\mathrm{N}_{5}\right)_{3}^{-}(\mathbf{1})$ and $\left(\mathrm{NaN}_{5}\right)_{2}\left(\mathrm{C}_{2} \mathrm{H}_{4} \mathrm{~N}_{4}\right)$ have been synthesized with ion exchange method. The formation of these crystals is mainly assisted by coordination bonding between the metal ion $\mathrm{Na}^{+}$, inorganic cyclo- $\mathrm{N}_{5}$ and organic components, which exceed the range of MOFs and shall be classified as CPs. Moreover, the diverse structure and thermal stabilization reveal another advantage of the crystal approach to access explosives with high performance.

\section{EXPERIMENTAL SECTION}

\section{Safety precautions}

Caution! The energetic coordination polymers with $c y$ clo- $\mathrm{N}_{5}{ }^{-}$are partly extremely high energetic compounds that may detonate violently; therefore they should be handled only on a very small scale while using appropriate safety precautions (safety glasses, face shield, leather coat, earthen equipment and shoes, Kevlar gloves and ear plugs).

\section{Materials and methods}

All reagents and solvents were purchased from SigmaAldrich, Aladdin, and Energy Chemical as analytical grade and were used as received. The single crystal X-ray diffraction (XRD) measurements were conducted on a Bruker Smart Apex II diffractometer using Mo-Ka radiation $(\lambda=0.71073 \AA)$ with a graphite monochromator at $170 \mathrm{~K}$. XRD data were collected with $\mathrm{Cu}$ Ka radiation on Bruker D8 ADVANCE scanning from $10^{\circ}$ to $80^{\circ}$. Fourier transform infrared spectroscopy (FT-IR) spectra were recorded on a Thermo Nicolet IS10 instrument. Raman spectra were collected using a Horiba-Jobin Yvon Labram HR800 Raman spectrometer with a $514.532 \mathrm{~nm}$ $\mathrm{Ar}^{+}$laser. A $50 \times$ objective was used to focus the laser beam. Differential scanning calorimeter (DSC) plots were acquired on a differential scanning calorimeter (Mettler Toledo DSC-1) at a scan rate of $5^{\circ} \mathrm{C} \mathrm{min}{ }^{-1}$ in perforated stainless steel containers under a nitrogen flow of $50 \mathrm{~mL} \mathrm{~min}^{-1}$. Transmission electron microscope (TEM) was performed on FEI Tecnai G2 F30 S-TWIN.

All computations were performed using the Gaussian 09 program [28] invoking hybrid HF-DFT calculations with the three-parameter gradient-corrected exchange potential of Becke and the gradient-corrected correlation potential of Lee, Yang, and Parr (B3LYP) $[29,30]$ using the $6-311 \mathrm{G}^{*}$ basis set. The structures were optimized for energy minimization before spectra acquisition and frequency calculations. The wave-functions of coordination polymers generated from Gaussian were imported into the software Multiwfn [31] to calculate the reduced density gradient (RDG) which was used for revealing noncovalent interactions [32] analysis.

\section{Crystallography}

Integration and scaling of intensity data was accomplished using the SAINT program [33]. The structures were solved by intrinsic using SHELXT2014 and refinement was carried out by a full-matrix least-squares technique using SHELXT2014 [34]. The hydrogen atoms were refined isotropically, and the heavy atoms were refined anisotropically. $\mathrm{N}-\mathrm{H}$ and $\mathrm{O}-\mathrm{H}$ hydrogens were located from different electron density maps, and $\mathrm{C}-\mathrm{H}$ hydrogens were placed in calculated positions and refined with a riding model. Data were corrected for the effects of absorption using SADABS [35].

\section{Synthetic procedures}

$\left[\mathbf{N a}\left(\mathrm{H}_{2} \mathrm{O}\right)\left(\mathbf{N}_{5}\right)\right] \cdot 2 \mathrm{H}_{2} \mathrm{O}$ : This compound was prepared according to our previously reported methods [21]. A solution of arylpentazole $(5.000 \mathrm{~g}, 26.18 \mathrm{mmol})$ and ferrous glycinate $(8.600 \mathrm{~g}, 42.16 \mathrm{mmol})$ in a mixed solution of $100 \mathrm{~mL}$ methyl alcohol and $100 \mathrm{~mL}$ acetonitrile was stirred at $-47^{\circ} \mathrm{C}$. After $30 \mathrm{~min}$, metachloroperbenzoic acid $(85 \%, 19.25 \mathrm{~g}, 94.82 \mathrm{mmol})$ was added in portions. The reaction mixture was maintained at $-43^{\circ} \mathrm{C}$ for $24 \mathrm{~h}$. The precipitate was removed by filtration, and the filtrate was vaporized under reduced pressure. The residue was suspended in $200 \mathrm{~mL}$ of water. The precipitate was filtered off and washed with $50 \mathrm{~mL}$ water. The filtrate was concentrated. After removing all the solvent under vacuum, the residue was purified by chromatography with ethyl alcohol/ethyl acetate (1:10-1:3 gradient elution). Crude $\mathrm{NaN}_{5}$ hydrate was obtained as an off-white product (427 mg, 19.56\%).

$\left[\mathrm{Na}_{5}\left(\mathbf{C H}_{6} \mathbf{N}_{3}\right)\left(\mathbf{N}_{5}\right)_{9}\right]^{3-} \quad$ (1): $1.0 \mathrm{mmol}$ of $\left[\mathrm{Na}\left(\mathrm{H}_{2} \mathrm{O}\right)-\right.$ $\left.\left(\mathrm{N}_{5}\right)\right] \cdot 2 \mathrm{H}_{2} \mathrm{O}(147 \mathrm{mg})$ and $1.0 \mathrm{mmol}$ of guanidine hydrochloride $(95.5 \mathrm{mg}$ ) was added to $15 \mathrm{~mL}$ methanol. The colorless solution was evaporated to dryness followed by repeated recrystallization in anhydrous ethanol to remove the sodium nitrate. Single crystal of $\mathbf{2}$ was obtained by maintaining 95\% alcohol solutions at ambient temperature for several days. Colorless crystals; yield: $80 \% ; T_{\mathrm{d}}=$ $118.4^{\circ} \mathrm{C}$; IR $(\mathrm{KBr}):=3,473,3,354,3,161,1,653,1,354$, $1,225,1,013,729 \mathrm{~cm}^{-1}$; Raman $\left(514.532 \mathrm{~nm}, 25^{\circ} \mathrm{C}\right): 1,172$, $1,008,118 \mathrm{~cm}^{-1}$.
$\left[\left(\mathrm{NaN}_{5}\right)_{2}\left(\mathrm{C}_{2} \mathrm{H}_{4} \mathrm{~N}_{4}\right)\right] \quad$ (2): $\quad 1.0 \mathrm{mmol}$ of $\left[\mathrm{Na}\left(\mathrm{H}_{2} \mathrm{O}\right)-\right.$ 
Table 1 Crystal data and structure refinement details of CPs 1 and $\mathbf{2}$

\begin{tabular}{|c|c|c|}
\hline Sample & 1 & 2 \\
\hline $\mathrm{CCDC}$ & 1544794 & 1575478 \\
\hline Empirical formula & $\mathrm{CH}_{6} \mathrm{~N}_{48} \mathrm{Na}_{5}$ & $\mathrm{CH}_{2} \mathrm{~N}_{7} \mathrm{Na}$ \\
\hline Temperature (K) & 170 & 173 \\
\hline Crystal system & Hexagonal & Trigonal \\
\hline Space group & $\mathrm{PG}_{3} / \mathrm{mmc}$ & $P 3_{2} 21$ \\
\hline$a(\AA)$ & $13.5635(11)$ & $9.687(4)$ \\
\hline$b(\AA)$ & $13.5635(11)$ & $9.687(4)$ \\
\hline$c(\AA)$ & $13.8295(12)$ & $9.585(4)$ \\
\hline$\alpha\left({ }^{\circ}\right)$ & 90.00 & 90.00 \\
\hline$\beta\left({ }^{\circ}\right)$ & 90.00 & 90.00 \\
\hline$\gamma\left({ }^{\circ}\right)$ & 120.00 & 120.00 \\
\hline Volume $\left(\AA^{3}\right)$ & 2203.3(4) & $779.0(6)$ \\
\hline$Z$ & 1.99992 & 6 \\
\hline$\rho_{\text {calc }}\left(\mathrm{g} \mathrm{cm}^{-3}\right)$ & 1.214 & 1.728 \\
\hline$\mu\left(\mathrm{mm}^{-1}\right)$ & 0.139 & 0.205 \\
\hline$F(000)$ & 806.0 & 408.0 \\
\hline Crystal size $\left(\mathrm{mm}^{3}\right)$ & $0.28 \times 0.17 \times 0.12$ & $0.28 \times 0.15 \times 0.12$ \\
\hline $2 \theta\left({ }^{\circ}\right)$ & 3.468 to 54.93 & 4.856 to 54.766 \\
\hline Reflections collected & 11891 & 1948 \\
\hline$R_{\text {int }} / R_{\text {sigma }}$ & $0.0564 / 0.0276$ & $0.0503 / 0.0809$ \\
\hline $\begin{array}{c}\text { Data/restraints/ } \\
\text { parameters }\end{array}$ & $975 / 0 / 54$ & $1160 / 6 / 85$ \\
\hline GOF on $F^{2}$ & 1.048 & 1.046 \\
\hline$R_{1} / \mathrm{w} R_{2}[I>=2 \sigma(I)]$ & $0.0339 / 0.0821$ & $0.0485 / 0.1105$ \\
\hline$R_{1} / \mathrm{w} R_{2}$ [all data] & $0.0457 / 0.0879$ & $0.0607 / 0.1240$ \\
\hline $\begin{array}{c}\text { Largest diff. } \\
\text { peak/hole }\left(\mathrm{e} \AA^{-3}\right)\end{array}$ & $0.25 /-0.23$ & $0.27 /-0.26$ \\
\hline
\end{tabular}

$\left.\left(\mathrm{N}_{5}\right)\right] \cdot 2 \mathrm{H}_{2} \mathrm{O}(147 \mathrm{mg})$ and $1.0 \mathrm{mmol}$ of 4 -amino-1,2,4triazole $(84 \mathrm{mg})$ was added to $15 \mathrm{~mL}$ methanol. Colorless rod-like crystal of 2 was obtained by maintaining the solutions at ambient temperature for several days. Colorless crystals; yield: $82 \%$; $T_{\mathrm{d}}=126.5^{\circ} \mathrm{C}$; IR $(\mathrm{KBr}):=3,367$, $3,292,3,123,2,988,2,038,1,614,1,517,1,451,1,370,1,229$, $1,188,1,070,974,945,872,670,624 \mathrm{~cm}^{-1}$; Raman $\left(514.532 \mathrm{~nm}, 25^{\circ} \mathrm{C}\right): 3,321,1,635,1,553,1,005,525 \mathrm{~cm}^{-1}$; Elemental analysis calcd. (\%) for $\mathrm{Na}_{2} \mathrm{C}_{2} \mathrm{H}_{4} \mathrm{~N}_{14}$ (270.13): $\mathrm{H}$ 1.49, N 72.59; found: H 1.51, N 72.51 .

\section{RESULTS AND DISCUSSION}

\section{Crystal structure}

The prepared CPs are analyzed by single-crystal XRD as shown in Table 1. Polymer $\mathbf{1}$ crystallizs into a 3D porous metal-inorganic framework with hexagonal crystal sys- tem and belongs to the $P 6_{3} / m m c$ space group. Here the polymer 1 represents a negatively charged structure, because sometimes charge-balancing cations in the cages is irregular and cannot be directly located in the crystal structure analysis. The detailed crystallographic data are provided in Supplementary Tables S1-S3. As depicted in Fig. 1, each sodium center $\mathrm{Na}(\mathrm{I})$ is hexahedral linked to pentazole linkers ( $\mathrm{Na}-\mathrm{N}$ bond length $2.462-2.499 \AA$ ), involving a $\eta^{1}$-bonding-type coordination. There are two types of pentazole rings in polymer 1 . The first type is one $\mathrm{N}_{5}$ ring attached to three $\mathrm{Na}(\mathrm{I})$ ions with coordination angle of $\sim 90$ and $140^{\circ}\left(\mathrm{Na}-\mathrm{N}_{5}-\mathrm{Na}\right)$, analogous to imidazolate rings in zeolite-imidazolate frameworks (ZIFs). The $\mathrm{N}$ atoms in these $\mathrm{N}_{5}$ rings are not completely coplane, with N1-N2-N3-N4 and N1-N5-N4-N3 torsion angles of $0.5^{\circ}$ and $0.7^{\circ}$, respectively. The second type is one $\mathrm{N}_{5}$ ring attached to four $\mathrm{Na}(\mathrm{I})$ ions with coordination angle of $\sim 150^{\circ}\left(\mathrm{Na}-\mathrm{N}_{5}-\mathrm{Na}\right)$. These $\mathrm{N}_{5}$ rings and $\mathrm{Na}(\mathrm{I})$ are of perfect planarity and the plane is perpendicular to $c$ axis. Moreover, the $\mathrm{N}_{5}$ rings in both types do not have identical $\mathrm{N}-\mathrm{N}$ bond lengths with average values found to be 1.316 and $1.320 \AA$ respectively. Through these connection modes, $8 \mathrm{Na}(\mathrm{I})$ ions and $9 \mathrm{~N}_{5}$ rings stitch into a cage of a $\sim 7.5 \AA$ diameter cavity with guanidine cation [C $\left.\left(\mathrm{NH}_{2}\right)_{3}\right]^{+}$placed in it. The cage as a repeat unit is further extended into microporous zeolite-like 3D framework with SOD topology (Fig. 1c). Upon removal of guest molecules, the structure of polymer 1 has a porosity of $\sim 35 \%$, as calculated with PLATON software [36].

In contrast to $\mathrm{CP} \mathbf{1}$, both $\mathrm{N}_{5}$ and 4-amino-1,2,4-triazole $(\mathrm{ATz})$ rings act as a linker in $\mathbf{2}$ and form a different kind of $3 \mathrm{D}$ porous framework with trigonal crystals in the $\mathrm{P3}_{2} 21$ space group (Tables S4, S5). As shown in Fig. 2 and Fig. S4, all of the $\mathrm{N}$ atoms in the pentazole ring are coordinated to $\mathrm{Na}(\mathrm{I})$. The atoms $\mathrm{N} 2$ and $\mathrm{N} 5$ participate in constructing the DNA-like double helix structure. The atoms $\mathrm{N} 1, \mathrm{~N} 3$, and $\mathrm{N} 4$, together with the $\mathrm{N}$ atoms in the $\mathrm{ATz}$ ring form links between the different helices, whose dihedral angle with the $a b$ plane is $\sim 70^{\circ}$. The $\mathrm{N}$ atoms in these $\mathrm{N}_{5}$ rings are not perfectly coplanar, with N1-N2$\mathrm{N} 3-\mathrm{N} 4$ and $\mathrm{N} 1-\mathrm{N} 5-\mathrm{N} 4-\mathrm{N} 3$ torsion angles being $0.5^{\circ}$ and $0.2^{\circ}$, respectively. As all of the $\mathrm{N}$ atoms in the $\mathrm{N}_{5}$ rings are in the same chemical environment that is affected by the weak coordination with the $\mathrm{Na}(\mathrm{I})$ ion and all the $\mathrm{Na}-\mathrm{N}$ bond length being $\sim 2.5 \AA$, the $\mathrm{N}_{5}$ ring retains almost identical N-N bond lengths; these bonds are of length $1.317 \AA$ A Six groups of double helices construct a channel of $9.5 \AA$ diameter, similar to that in zeolites (Fig. 2c). However, in contrast to the typical zeolites, the channel in $\mathbf{2}$ is filled with coordinated ATz rings, which implies that 

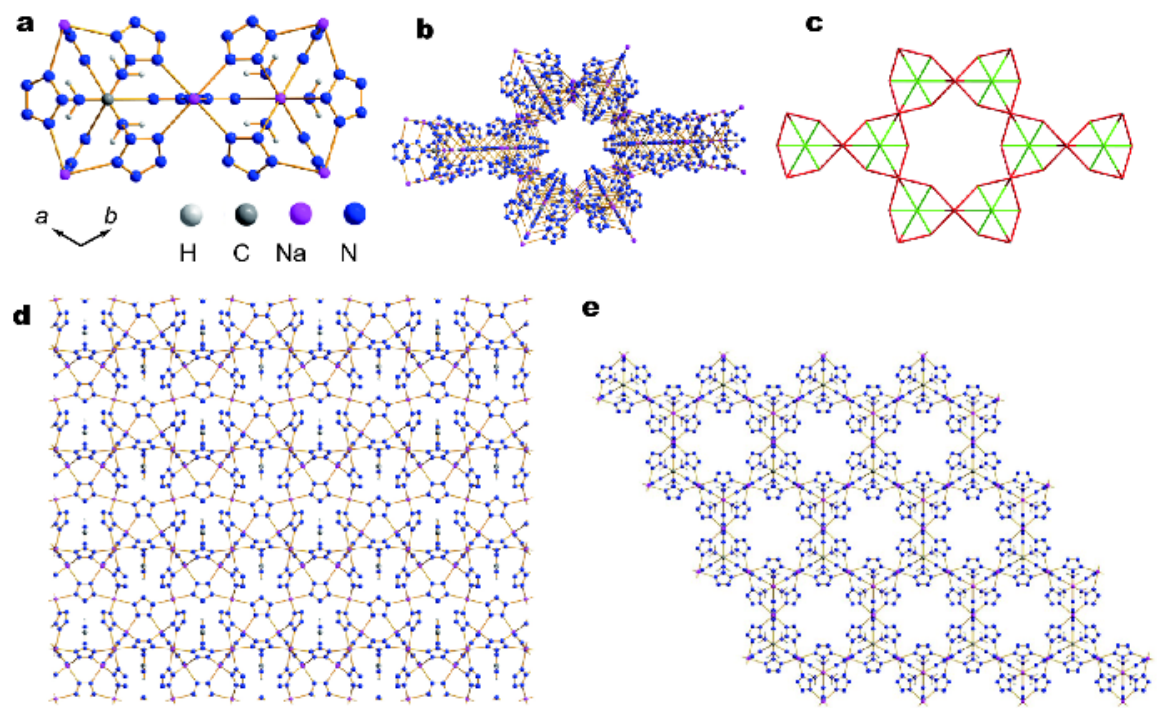

Figure 1 Crystal structure of 1 . (a) The coordination mode of $\mathrm{Na}^{+}$in CP 1. (b) Perspective view of the coordination mode along $\boldsymbol{c}$ axis. (c) A topological net of simplified unit cell. (d) Unit cell stacking diagram view along $\boldsymbol{b}$ axis $(4 \times 4 \times 4)$. (e) Unit cell stacking diagram view along $\boldsymbol{c}$ axis $(4 \times 4 \times 4)$. Carbon, hydrogen, nitrogen, oxygen, and sodium atoms are shown in gray, white, blue, red, and purple respectively.

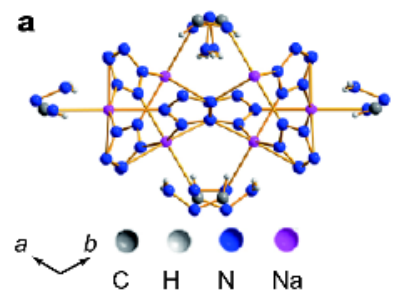

d b

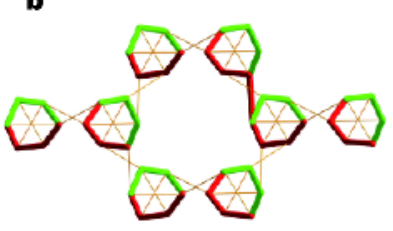

c

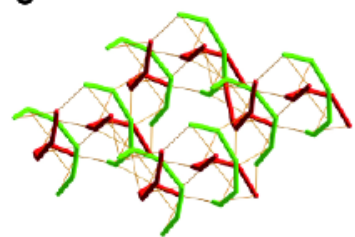

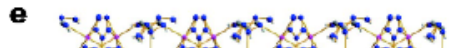
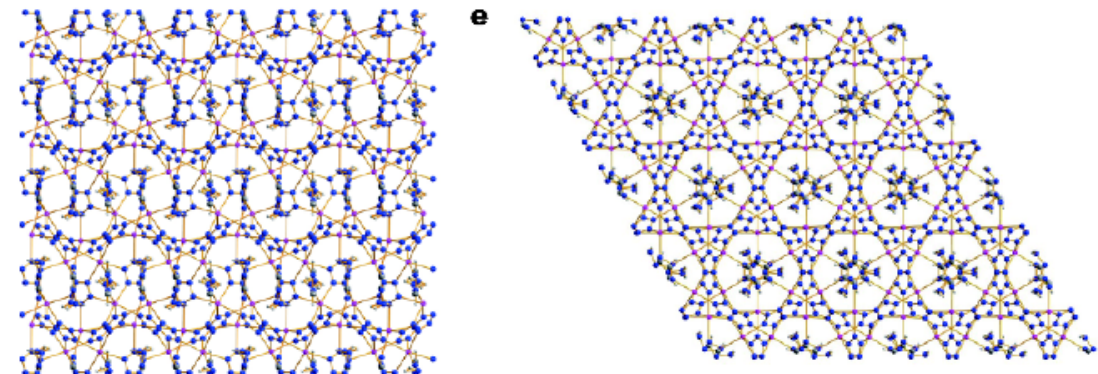

Figure 2 Crystal structure of 2. (a) The coordination mode of $\mathrm{Na}^{+}$in CP 2. (b) A topological net of simplified unit cell. (c) Two-helical structure of simplified unit cell. (d) Unit cell stacking diagram view along $a$ axis $(4 \times 4 \times 4)$. (e) Unit cell stacking diagram view along $c$ axis $(4 \times 4 \times 4)$. Carbon, hydrogen, nitrogen, oxygen, and sodium atoms are shown in gray, white, blue, red, and purple respectively.

the polymer is not porous.

\section{Spectra analysis}

A comparison of the spectra of CPs $\mathbf{1}$ and $\mathbf{2}$ together with that of the starting material is shown in Fig. 3. This figure reveals that several band shifts occur when the three CPs are formed. Furthermore, it indicates the existence of weak interactions between the individual components even when they are not directly coordinated. Both the coordination bond and weak interactions cause a deformation of cyclo- $\mathrm{N}_{5}{ }^{-}$in frameworks. From the geometric parameters of the $\mathrm{N}_{5}$ ring in $\mathbf{1}$ and 2 , it can be concluded that the tri- and tetradentate cyclo- $\mathrm{N}_{5}^{-}\left(\mathrm{N}_{5}-1 \mathrm{~A}\right.$ and $\mathrm{N}_{5}-1 \mathrm{~B}$ in 1 ), pentadentate cyclo- $\mathrm{N}_{5}^{-}$anion $\left(\mathrm{N}_{5}-2\right)$ all represent $C_{2 \mathrm{v}}$ symmetry. However, the coordination effect between $\mathrm{Na}^{+}$and cyclo- $\mathrm{N}_{5}{ }^{-}$in the CPs is weaker than that 

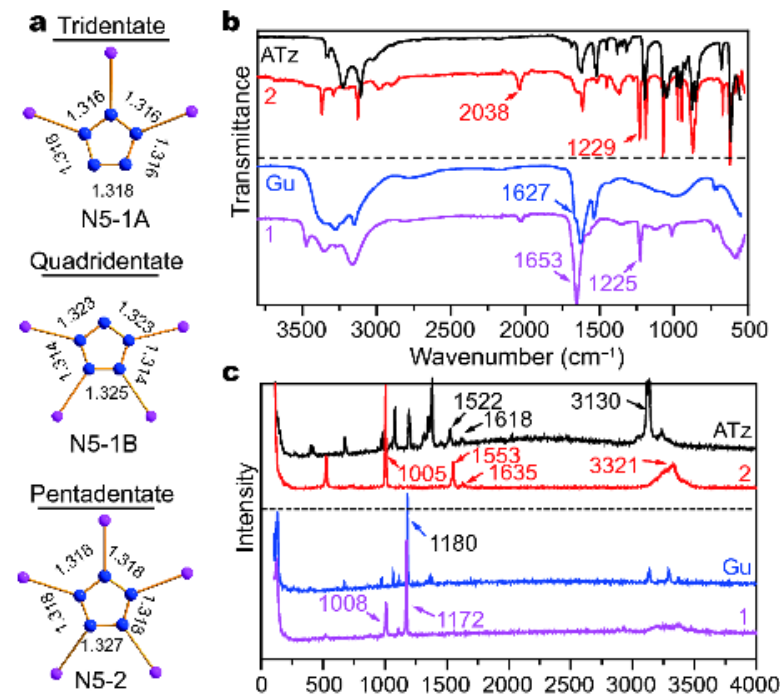

c

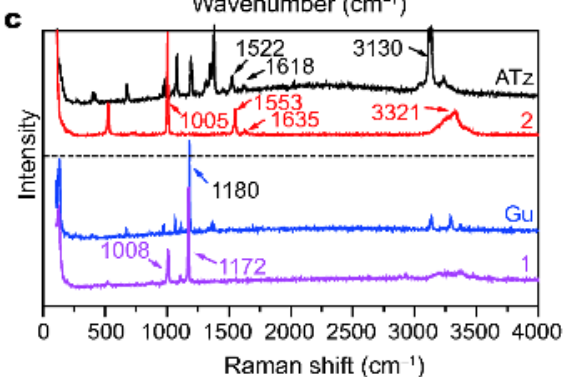

Figure 3 Geometric parameter, FT-IR and Raman spectra of CPs 1 and 2. (a) Bond length of tri- quadri-, and pentadentate-cyclo- $\mathrm{N}_{5}{ }^{-}$in $\mathrm{CPs} \mathbf{1}$ and 2. (b) FT-IR spectra of CPs $\mathbf{1}$ and $\mathbf{2}, \mathrm{Gu}$ (guanidine hydrochloride), and $\mathrm{ATz}$ (4-amino-1,2,4-triazole). (c) Raman spectra of CPs 1 and 2, Gu, and ATz.

of previously reported transition metal- $\mathrm{N}_{5}{ }^{-}$complexes. So the bond lengths in cyclo- $\mathrm{N}_{5}^{-}$, especially $\mathrm{N}_{5}-2$, vary slightly and they are also close to $D_{5 \mathrm{~h}}$ symmetry, with IR spectra at 1,225 and $1,229 \mathrm{~cm}^{-1}$ observed respectively in Fig. 3a. From Raman spectra, the typical cyclo- $\mathrm{N}_{5}^{-}$in $C_{2 \mathrm{v}}$ symmetry with significantly different bond length in $\mathrm{N}_{5^{-}}$ $1 \mathrm{~B}$ compared with previous transition metal complexes represents a strong peak at $1,170-1,190 \mathrm{~cm}^{-1}$ in Fig. 3b; the other cyclo- $\mathrm{N}_{5}^{-}$in $C_{2 \mathrm{v}}$ symmetry including $\mathrm{N}_{5}-1 \mathrm{~A}$ and $\mathrm{N}_{5}$-2 with similar bond length which is also close to $D_{5 \mathrm{~h}}$ symmetry shows a strong peak at $1,000-1,010 \mathrm{~cm}^{-1}$. That is to say although $\mathrm{N}_{5}-1 \mathrm{~A}$ and $\mathrm{N}_{5}-2$ belongs to $C_{2 \mathrm{v}}$ symmetry in theoretical, but they indeed present the properties of $D_{5 \mathrm{~h}}$ symmetry because of very close N-N bond length. Combining previous reports and the results of this paper, cyclo- $\mathrm{N}_{5}{ }^{-}$can provide up to five coordination positions and all of them show $C_{2 \mathrm{v}}$ symmetry. The absolute configuration of $D_{5 \mathrm{~h}}$ symmetry is difficult to be achieved even in the pentadentate $c y c l o-\mathrm{N}_{5}{ }^{-}\left(\mathrm{N}_{5}-2\right)$ in which each $\mathrm{N}$ atom is at almost the same chemical conditions or nondentate cyclo- $\mathrm{N}_{5}^{-}\left[\mathrm{Mg}\left(\mathrm{H}_{2} \mathrm{O}\right)_{6}\left(\mathrm{~N}_{5}\right)_{2}\right] \cdot 4 \mathrm{H}_{2} \mathrm{O}$ [23].

The experimental powder XRD (PXRD) patterns for the CPs $\mathbf{1}$ and $\mathbf{2}$ are shown in Fig. S4. Comparison of the experimental XRD pattern with the calculated pattern for the simulated unit cell shows good agreement of the reflection positions. The PXRD patterns of the CPs differed from those of the constituents, confirming the formation

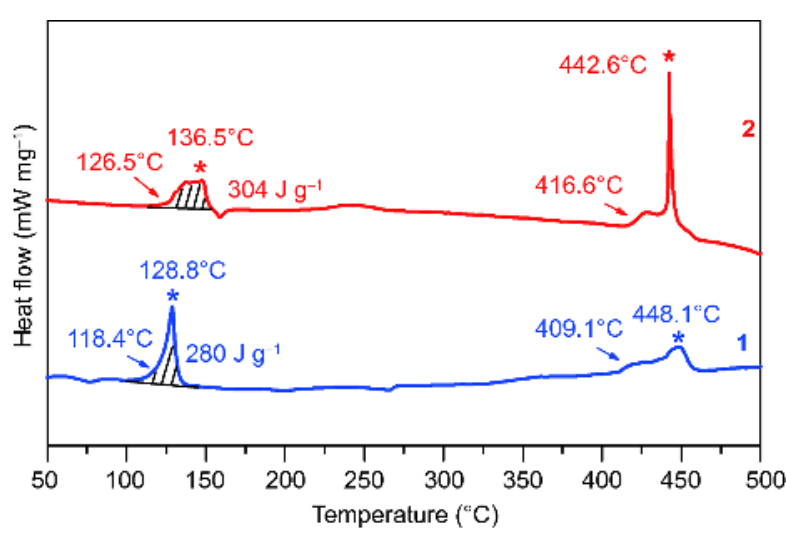

Figure 4 Differential scanning calorimetry spectra of CPs $\mathbf{1}$ and 2. The point of decomposition temperature is onset temperature.

of a new complex phase. HRTEM pictures confirm the new formed phases of prepared samples are highly ordered structures (Fig. S5); meanwhile, they also show that the cyclo- $\mathrm{N}_{5}^{-}$is unstable under electron beam.

\section{Thermal properties}

The DSC curves of the synthesized CPs are shown in Fig. 4. No endothermic peaks can be observed below $100^{\circ} \mathrm{C}$, which suggests that the polymers contain very little water. The first exothermic peak of $\mathbf{1}$ and $\mathbf{2}$ is observed at 118.4 and $126.5^{\circ} \mathrm{C}$ (onset temperature). This suggests a decomposition of the CPs takes place during the heating sequence and from an assessment of the amount of heat released. The products of CPs $\mathbf{1}$ and $\mathbf{2}$ heated at 118.4 and $126.5^{\circ} \mathrm{C}$ were tested with $\mathrm{FeCl}_{3}$ solution and the color of solution turned into red, which indicated that both of them have decomposed from cyclo- $\mathrm{N}_{5}^{-}$to $\mathrm{N}_{3}^{-}$(Fig. S6). The decomposition point, compared with that of the $1 \mathrm{D}$ structure $\left[\mathrm{Na}\left(\mathrm{H}_{2} \mathrm{O}\right)\left(\mathrm{N}_{5}\right)\right] \cdot 2 \mathrm{H}_{2} \mathrm{O}$, is increased by 7.4 and $15.5^{\circ} \mathrm{C}$ in 1 and 2 , respectively. These observations indicate that the coordination and hydrogen bonding interactions (Fig. S7) is beneficial for stabilizing the $\mathrm{N}_{5}$ ring. From another point of view, the identical N-N bond lengths are indicative of better conjugation and stability.

\section{Detonation properties}

The heat of detonation is greatly affected by the standard enthalpies of formation of energetic CPs, which is calculated using their constant-volume combustion energies. The constant-volume combustion energies $\left(Q_{\mathrm{V}}\right)$ of CP 1 and 2 were measured by an oxygen-bomb calorimeter, from which the standard molar enthalpy of combustion $\left(\Delta_{\mathrm{C}} H_{\mathrm{m}}{ }^{\ominus}\right)$ is estimated by using an equation $\Delta_{\mathrm{C}} H_{\mathrm{m}}{ }^{{ }^{\circ}}=\Delta_{\mathrm{C}} U_{\mathrm{m}}{ }^{{ }^{\circ}}$ $+\Delta n R T$. The standard enthalpies of formation for CP 1 
Table 2 Properties of 1 and 2 and comparison with TNT, RDX, and HMX

\begin{tabular}{|c|c|c|c|c|c|c|c|c|}
\hline & $\begin{array}{c}\rho^{\mathrm{a}} \\
\left(\mathrm{g} \mathrm{cm}^{-3}\right)\end{array}$ & $\begin{array}{l}N^{\mathrm{b}} \\
(\%)\end{array}$ & $\begin{array}{l}\Omega^{\mathrm{c}} \\
(\%)\end{array}$ & $\begin{array}{c}\Delta H_{\mathrm{f}}^{\mathrm{d}} \\
\left(\mathrm{kJ} \mathrm{mol}{ }^{-1}\right)\end{array}$ & $\begin{array}{c}T_{\mathrm{d}}^{\mathrm{e}} \\
\left({ }^{\circ} \mathrm{C}\right)\end{array}$ & $\begin{array}{c}Q^{f} \\
\left(\mathrm{kcal} \mathrm{g}^{-1}\right)\end{array}$ & $\begin{array}{c}D^{\mathrm{g}} \\
\left(\mathrm{m} \mathrm{s}^{-1}\right)\end{array}$ & $\begin{array}{c}P^{\mathrm{h}} \\
(\mathrm{GPa})\end{array}$ \\
\hline 1 & 1.19 & 83.48 & -14.9 & 1015 & 118.4 & 0.329 & 4407 & 6.5 \\
\hline 2 & 1.70 & 72.59 & -41.5 & 902 & 126.5 & 1.650 & 7863 & 26.4 \\
\hline HMX & 1.90 & 37.84 & -21.6 & 105 & 279 & 1.320 & 8900 & 38.4 \\
\hline RDX & 1.81 & 37.84 & -21.6 & 80 & 210 & 1.386 & 8600 & 33.9 \\
\hline TNT & 1.65 & 18.50 & -74.0 & -67 & 290 & 0.897 & 7178 & 20.5 \\
\hline
\end{tabular}

a) Recalculated from low-temperature X-ray densities $\left(\rho=\rho_{\mathrm{T}} /\left(1+\alpha_{\mathrm{V}}\left(298-T_{0}\right)\right) ; \alpha_{\mathrm{V}}=1.5 \times 10^{-4} \mathrm{~K}^{-1}\right)$. b) Nitrogen content. c) Oxygen balance. d) Calculated heat of formation. e) Thermal decomposition temperature (onset) under nitrogen gas (DSC, $5^{\circ} \mathrm{C}$ min ${ }^{-1}$ ). $\mathrm{f}$ ) The heat of detonation. $\mathrm{g}$ ) Detonation velocity. h) Detonation pressure.

and 2 are obtained via the known $\Delta_{\mathrm{f}} H_{\mathrm{m}}{ }^{{ }}$of the combustion products and $\Delta_{\mathrm{C}} H_{\mathrm{m}}{ }^{\theta}$ of CP $\mathbf{1}$ and 2 (see ESI).

Heat of detonation $(Q)$, detonation velocity $(D)$, and detonation pressure $(P)$ are pivotal parameters for energetic CPs. On the basis of the largest exothermic principle proposed by Kamlet-Jacobs (K-J) [37], We employed a widely used empirical method $[38,39]$ proposed by Pang and coworkers [40] to investigate the detonation properties of metal-containing energetic CPs. The detonation reactions of CP $\mathbf{1}$ and $\mathbf{2}$ are described by Equation S5, 6, and the detonation properties are calculated by K-J equations (see Supporting Information). As shown in Table 2 , the nitrogen contents $(>66 \%)$ and heats of formation $\left(>800 \mathrm{~kJ} \mathrm{~mol}^{-1}\right)$ for the two CPs are much higher than those of the traditional energetic materials (TNT, RDX, and HMX). But only the heat of detonation for CP $2\left(1.65 \mathrm{kcal} \mathrm{g}^{-1}\right)$ is higher than those of TNT, RDX, HMX, and CL-20 (about $1.5 \mathrm{kcal} \mathrm{g}^{-1}$ ). The $D$ and $P$ of CP 2 are calculated to be $7,863 \mathrm{~m} \mathrm{~s}^{-1}$ and $26.44 \mathrm{GPa}$, respectively, which are slightly higher than TNT. The poor detonation performance of CP $\mathbf{1}$ is attributed to their low density $\left(<1.3 \mathrm{~g} \mathrm{~cm}^{-3}\right)$ caused by porous structure. From another point of view, this porous structure may hold other small energetic materials and improve the energetic performance.

\section{CONCLUSIONS}

The target of our designs is to obtain multidimensional structure that possess the potential high energy (provided by $\mathrm{N}_{5}$ ) and better stability compared with previously reported species (through coordination and hydrogen bonding provided by framework). With this strategy, guanidine hydrochloride and ATz standing for the cation and neutral molecule with similar size are employed to coordinate with $\mathrm{NaN}_{5}$. Two novel energetic $\mathrm{CPs},\left(\mathrm{NaN}_{5}\right)_{5^{-}}$ $\left[\left(\mathrm{CH}_{6} \mathrm{~N}_{3}\right) \mathrm{N}_{5}\right]\left(\mathrm{N}_{5}\right)_{3}^{-}$and $\left(\mathrm{NaN}_{5}\right)_{2}\left(\mathrm{C}_{2} \mathrm{H}_{4} \mathrm{~N}_{4}\right)$, were synthesized and characterized. From crystal structure analysis, the cyclo- $\mathrm{N}_{5}^{-}$anion shows a unique coordination ability that some other polynitrogen species do not have. In CPs $\mathbf{1}$ and 2, it can form tri-, quadri- and pentadentate with central $\mathrm{Na}^{+}$due to the various coordination positions and represents two different structures. As a result of the coordination effect, hydrogen bonding and structural modification, cyclo- $\mathrm{N}_{5}^{-}$anions in CPs $\mathbf{1}$ and 2 possess better thermal stability $\left(118.4\right.$ and $126.5^{\circ} \mathrm{C}$ as onset decomposition temperature) than that in $\mathrm{NaN}_{5}$ and its hydrate $\left[\mathrm{Na}\left(\mathrm{H}_{2} \mathrm{O}\right)\left(\mathrm{N}_{5}\right)\right] \cdot 2 \mathrm{H}_{2} \mathrm{O}$. Moreover, the fully coordination of possible positions prevents $\mathrm{H}_{2} \mathrm{O}$ entering the crystal and generates anhydrate compounds, which is a big forward step to obtain final energetic materials. The 3D CPs 1 and 2 also show high heats of formation $\left(>800 \mathrm{~kJ} \mathrm{~mol}^{-1}\right)$. Considering their detonation properties, the anhydrous products of sodium-pentazole species with better thermal stability and higher heats of formation are potential to being applied in HEDMs.

\section{Received 1 March 2018; accepted 30 March 2018;} published online 27 April 2018

1 Christe KO. Polynitrogen chemistry enters the ring. Science, 2017, 355: 351-351

2 Klapötke TM. Chemistry of High-Energy Materials. Boston: De Gruyter, 2017

3 Yin P, Shreeve JM. Advances in heterocyclic chemistry. London: Elsevier, 2017, 121: 89-131

4 Zhang Q, Shreeve J'M. Energetic ionic liquids as explosives and propellant fuels: a new journey of ionic liquid chemistry. Chem Rev, 2014, 114: 10527-10574

5 Singh RP, Gao H, Meshri DT, Shreeve JM. High Energy Density Materials. Berlin: Springer, 2007, 35-83

6 Chen SL, Yang ZR, Wang BJ, et al. Molecular perovskite highenergetic materials. Sci China Mater, 2018, 61: 1123-1128

7 Gao H, Shreeve J'M. Azole-based energetic salts. Chem Rev, 2011, 111: 7377-7436

8 Fischer N, Fischer D, Klapötke TM, et al. Pushing the limits of energetic materials-the synthesis and characterization of dihydroxylammonium 5,5'-bistetrazole-1,1'-diolate. J Mater Chem, 2012, 22: 20418-20422 
9 Zhang S, Yang Q, Liu X, et al. High-energy metal-organic frameworks (HE-MOFs): Synthesis, structure and energetic performance. Coord Chem Rev, 2016, 307: 292-312

10 Li S, Wang Y, Qi C, et al. 3D energetic metal-organic frameworks: synthesis and properties of high energy materials. Angew Chem Int Ed, 2013, 52: 14031-14035

11 McDonald KA, Seth S, Matzger AJ. Coordination polymers with high energy density: an emerging class of explosives. Cryst Growth Des, 2015, 15: 5963-5972

12 Zhang J, Shreeve JM. Time for pairing: cocrystals as advanced energetic materials. CrystEngComm, 2016, 18: 6124-6133

13 Landenberger KB, Bolton O, Matzger AJ. Energetic-energetic cocrystals of diacetone diperoxide (DADP): dramatic and divergent sensitivity modifications via cocrystallization. J Am Chem Soc, 2015, 137: 5074-5079

14 Haiges R, Boatz JA, Vij A, et al. Polyazide chemistry: preparation and characterization of $\mathrm{Te}\left(\mathrm{N}_{3}\right)_{4}$ and $\left[\mathrm{P}\left(\mathrm{C}_{6} \mathrm{H}_{5}\right)_{4}\right]_{2}\left[\mathrm{Te}\left(\mathrm{N}_{3}\right)_{6}\right]$ and evidence for $\left[\mathrm{N}\left(\mathrm{CH}_{3}\right)_{4}\right]\left[\mathrm{Te}\left(\mathrm{N}_{3}\right)_{5}\right]$. Angew Chem Int Ed, 2003, 42: 5847-5851

15 Fehlhammer WP, Beck W. Azide chemistry-an inorganic perspective, part I metal-azides: overview, general trends and recent developments. Z Anorg Allg Chem, 2013, 639: 1053-1082

16 Christe KO, Wilson WW, Sheehy JA, et al. $\mathrm{N}_{5}{ }^{+}$: a novel homoleptic polynitrogen ion as a high energy density material. Angew Chem Int Ed, 1999, 38: 2004-2009

17 Haiges R, Schneider S, Schroer T, et al. High-energy-density materials: synthesis and characterization of $\mathrm{N}_{5}^{+}\left[\mathrm{P}\left(\mathrm{N}_{3}\right)_{6}\right]^{-}, \mathrm{N}_{5}^{+}\left[\mathrm{B}\left(\mathrm{N}_{3}\right)_{4}\right]^{-}$, $\mathrm{N}_{5}^{+}\left[\mathrm{HF}_{2}\right]^{-} \cdot n \mathrm{HF}, \mathrm{N}_{5}^{+}\left[\mathrm{BF}_{4}\right]^{-}, \mathrm{N}_{5}^{+}\left[\mathrm{PF}_{6}\right]^{-}$, and $\mathrm{N}_{5}^{+}\left[\mathrm{SO}_{3} \mathrm{~F}\right]^{-}$. Angew Chem Int Ed, 2004, 43: 4919-4924

18 Vij A, Pavlovich JG, Wilson WW, et al. Experimental detection of the pentaazacyclopentadienide (pentazolate) anion, cyclo- $\mathrm{N}_{5}^{-}$. Angew Chem Int Ed, 2002, 41: 3051-3054

19 Östmark H, Wallin S, Brinck T, et al. Detection of pentazolate anion $\left(\right.$ cyclo- $\left.\mathrm{N}_{5}{ }^{-}\right)$from laser ionization and decomposition of solid p-dimethylaminophenylpentazole. Chem Phys Lett, 2003, 379: 539-546

20 Steele BA, Oleynik II. Sodium pentazolate: A nitrogen rich high energy density material. Chem Phys Lett, 2016, 643: 21-26

21 Bazanov B, Geiger U, Carmieli R, et al. Detection of cyclo- $\mathrm{N}_{5}^{-}$in THF solution. Angew Chem Int Ed, 2016, 55: 13233-13235

22 Steele BA, Stavrou E, Crowhurst JC, et al. High-pressure synthesis of a pentazolate salt. Chem Mater, 2017, 29: 735-741

23 Zhang C, Sun C, Hu B, et al. Synthesis and characterization of the pentazolate anioncyclo- $\mathrm{N}_{5}^{-}$in $\left(\mathrm{N}_{5}\right)_{6}\left(\mathrm{H}_{3} \mathrm{O}\right)_{3}\left(\mathrm{NH}_{4}\right)_{4} \mathrm{Cl}$. Science, 2017, 355: 374-376

24 Xu Y, Wang Q, Shen C, et al. A series of energetic metal pentazolate hydrates. Nature, 2017, 549: 78-81

25 Zhang C, Yang C, Hu B, et al. A symmetric $\mathrm{Co}\left(\mathrm{N}_{5}\right)_{2}\left(\mathrm{H}_{2} \mathrm{O}\right)_{4} \cdot 4 \mathrm{H}_{2} \mathrm{O}$ high-nitrogen compound formed by cobalt(II) cation trapping of a cyclo- $\mathrm{N}_{5}^{-}$anion. Angew Chem Int Ed, 2017, 56: 4512-4514

26 Xu Y, Wang P, Lin Q, et al. A carbon-free inorganic-metal complex consisting of an all-nitrogen pentazole anion, a $\mathrm{Zn}(\mathrm{ii})$ cation and $\mathrm{H}_{2} \mathrm{O}$. Dalton Trans, 2017, 46: 14088-14093

27
Zhang W, Wang K, Li J, et al. Stabilization of the pentazolate anion in a zeolitic architecture with $\mathrm{Na}_{20} \mathrm{~N}_{60}$ and $\mathrm{Na}_{24} \mathrm{~N}_{60}$ nanocages. Angew Chem Int Ed, 2018, 57: 2592-2595

28 Frisch MJ, Trucks GW, Schlegel HB, et al. Gaussian 09, Revision A.02, Gaussian, Inc, Wallingford CT, 2009

29 Becke AD. Density-functional thermochemistry. III. The role of exact exchange. J Chem Phys, 1993, 98: 5648-5652

30 Lee C, Yang W, Parr RG. Development of the Colle-Salvetti correlation-energy formula into a functional of the electron density. Phys Rev B, 1988, 37: 785-789

31 Lu T, Chen F. Multiwfn: A multifunctional wavefunction analyzer. J Comput Chem, 2012, 33: 580-592

32 Johnson ER, Keinan S, Mori-Sanchez P, et al. Revealing noncovalent interactions. J Am Chem Soc, 2010, 132: 6498-6506

33 SAINT v7.68A Bruker AXS Inc: Madison, WI, 2009

34 Sheldrick GM. SHELXL-2014/7, University of Göttingen, Germany, 2014

35 SADABS v2008/1 Bruker AXS Inc.: Madison, WI, 2008

36 Spek AL. PLATON, An integrated tool for the analysis of the results of a single crystal structure determination. Acta Crystallogr sect A, 1990, 46: C34

37 Kamlet MJ, Jacobs SJ. Chemistry of detonations. I. A simple method for calculating detonation properties of $\mathrm{C}-\mathrm{H}-\mathrm{N}-\mathrm{O}$ explosives. J Chem Phys, 1968, 48: 23-35

38 Zhang $\mathrm{Y}$, Zhang $\mathrm{S}$, Sun L, et al. A solvent-free dense energetic metal-organic framework (EMOF): to improve stability and energetic performance via in situ microcalorimetry. Chem Commun, 2017, 53: 3034-3037

39 Xu Y, Liu W, Li D, et al. In situ synthesized 3D metal-organic frameworks (MOFs) constructed from transition metal cations and tetrazole derivatives: a family of insensitive energetic materials. Dalton Trans, 2017, 46: 11046-11052

40 Wang $\mathrm{Y}$, Zhang J, Su H, et al. A simple method for the prediction of the detonation performances of metal-containing explosives. J Phys Chem A, 2014, 118: 4575-4581

Acknowledgements This work was financially supported by the National Natural Science Foundation of China (11702141, 21771108, and U1530101). The authors gratefully acknowledge Dongxue Li (College of Chemical Engineering, Nanjing Tech University) for her tests of the Raman spectra.

Author contributions Wang PC, Lin QH and Lu M conceived the idea, designed the experiments and co-wrote the manuscript. Wang PC and $\mathrm{Xu}$ YG conducted synthetic experiments, calculations, and performed the DSC, TGA, PXRD measurements. Wang Q and Shao YL assisted the synthetic experiments. Wang PC assisted the calculations. Xu YG performed the single-crystal XRD measurements. All authors discussed the results and commented on the manuscript.

Conflict of interest The authors declare no conflict of interest.

Supplementary information Experimental details and supporting data are available in the online version of the paper. 

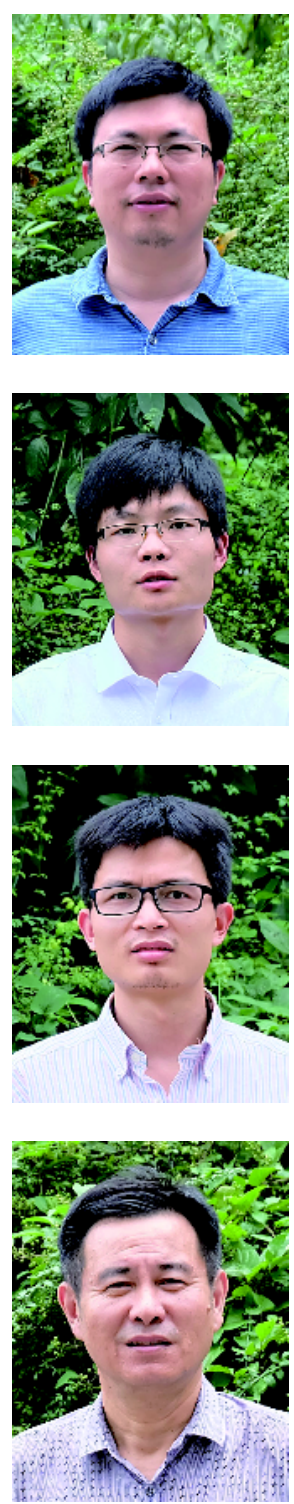

Pengcheng Wang obtained his BSc in 2008 and PhD in 2013 at Nanjing University of Science and Technology (NJUST), and was a postdoc at the National Institute of Advanced Industrial Science and Technology (AIST) from 2013 to 2014. He joined NJUST in 2014. His current research interest is in the synthesis and crystal engineering of energetic materials.

Yuangang Xu was born in 1990. He is a PhD candidate of applied chemistry in NJUST. His research focuses on the synthesis of nitrogen-rich energetic materials.

Qiuhan Lin obtained his BSc in 2008 and PhD in 2013 at Beijing Institute of Technology. He joined NJUST as an associate professor in 2014. His current research interest is in the synthesis and crystal engineering of energetic salts.

Ming Lu obtained his BSc in 1984, MSc in 1989 and PhD in 1999 at NJUST. He then became a professor in 2001. His current research interest focuses on the synthesis and crystal engineering of energetic materials, pharmaceutical intermediates and green chemistry.

\section{多齿五唑 $\mathbf{N}_{5}{ }^{-}$的自组装纳米含能配位聚合物}

\section{王鹏程 ${ }^{\dagger}$ 许元刚 ${ }^{\dagger}$, 王乾, 郡艳丽, 林秋汉 ${ }^{*}$, 陆明 ${ }^{*}$}

摘要 在含能材料领域, 通过协同作用形成聚合物已成为改善或增强现有含能物质性能的一种新技术. 本文将胍阳离子 $\mathrm{CH}_{3} \mathrm{H}_{6}{ }^{+}(\mathrm{GU})$ 和氨 基-1,2,4-三唑 $\mathrm{C}_{2} \mathrm{H}_{4} \mathrm{~N}_{4}(\mathrm{ATZ})$ 与 $\mathrm{NaN}_{5}$ 一起结晶, 通过自组装过程分别制备了两种新型含能配位聚合物 $(\mathrm{CPs}),\left(\mathrm{NaN}_{5}\right)_{5}\left[\left(\mathrm{CH}_{3} \mathrm{H}_{6}\right) \mathrm{N}_{5}\right]\left(\mathrm{N}_{5}\right)_{3}(\mathbf{1})$ 和 $\left(\mathrm{NaN}_{5}\right)_{2}\left(\mathrm{C}_{2} \mathrm{H}_{4} \mathrm{~N}_{4}\right)(2)$. 晶体结构表明, 在固体状态下, 螯合的五唑阴离子实现了与其他有机成分共存. 聚合物 $1, \mathrm{Na}^{+}$和 $\mathrm{N}_{5}{ }^{-}$形成笼状, 并将胍 阳离子 $\left[\mathrm{C}\left(\mathrm{NH}_{2}\right)_{3}\right]^{+}$围在里面; 而聚合物 2 是一个混合配体体系, $\mathrm{N}_{5}{ }^{-}$和 $\mathrm{ATZ}$ 与 $\mathrm{Na}^{+}$分别形成两个独立但相互交织的网. 这些都说明了通过结晶 形成配位聚合物, 来改变含能材料的特定性能是可行的. 受益于配位和弱相互作用, 两种聚合物的热分解温度分别从 $111^{\circ} \mathrm{C}($ 一维结构 $[\mathrm{Na}$ $\left.\left.\left(\mathrm{H}_{2} \mathrm{O}\right)\left(\mathrm{N}_{5}\right)\right] \cdot 2 \mathrm{H}_{2} \mathrm{O}\right)$ 提高到了 118.4 和 $126.5^{\circ} \mathrm{C}$. 此外, 他们成功地除去了产物中的结晶水, 成为具有高生成热特点的五唑无水盐 $(>$ $\left.800 \mathrm{~kJ} \mathrm{~mol}^{-1}\right)$. 聚合物 $\mathbf{1}$ 和 $\mathbf{2}$ 比传统能量材料高得多的生成热, 表明 $\mathrm{N}_{5}{ }^{-}$作为高能量密度材料(HEDMs)的前驱体, 具有很好的前景. 